\title{
ITGA9 Gene
}

National Cancer Institute

\section{Source}

National Cancer Institute. IT GA9 Gene. NCI Thesaurus. Code C150270.

This gene is involved in cell-matrix adhesion-dependent signaling. 